\title{
TAIWAN'S DEVELOPMENT AID TO \\ LATIN AMERICA AND THE CARIBBEAN AND THE ONE CHINA POLICY
}

Lorenzo Maggiorelli(a)

COOPERACIÓN PARA EL DESARROLLO PROVENIENTE DE TAIWAN

PARA AMÉRICA LATINA Y LA POLÍTICA DE UNA SOLA CHINA

A AJUDA AO DESENVOLVIMENTO DE TAIWAN EM AMÉRICA

LATINA E O CARIBE, E A POLÍTICA DE UMA CHINA

Fecha de recepción: 5 de abril del 2019

Fecha de aprobación: 19 de junio del 2019

Disponible en línea: 1 de julio del 2019

Sugerencia de citación:

Maggiorelli, L. (2019). Taiwan's development aid to Latin America and the Caribbean and the One China policy. Razón Crítica, 7, 177-208, doi: 10.21789/25007807.1513

(a) PhD in Political Science from the University of the Andes (Colombia). 2019 Taiwan Fellow, currently visiting scholar at National Taiwan University, Taiwan

https://orcid.org/0000-0002-4182-8627

1.maggiorelli10@uniandes.edu.co 


\section{A B S T R A C T}

Since slightly more than half of the countries that recognize Taiwan are located in Latin America and the Caribbean -LAC-, Taipei and Beijing have been striving to achieve diplomatic recognition in the region, using development aid as a foreign policy tool to gain diplomatic partners. This article analyzes statements by governmental officers and previous literature, as well as quantitative development aid data, in order to assess the impact of Taiwanese aid program in LAC. It concludes that Taipei has indeed some leverage to contain China's advancement in the region, due to its status of democratic country, its history of successful development and, especially, its strong ties with Washington. Nevertheless, in the face of China's renewed efforts in imposing its "One China Policy", Taiwan's possibilities to avoid diplomatic isolation remain uncertain.

KEYWORDS: Taiwan, foreign aid, Latin America and the Caribbean, China, One China Policy. 


\section{R E S U M E N}

Dado que poco más de la mitad de los países que reconocen a Taiwán se encuentran en América Latina y el Caribe, Taipéi y Pekín se han esforzado por lograr reconocimiento diplomático en la región, utilizando programas de ayuda para el desarrollo para conseguir socios diplomáticos. Este artículo analiza las declaraciones de los funcionarios gubernamentales y la literatura anterior, así como los datos cuantitativos de la ayuda para el desarrollo, a fin de evaluar el impacto del programa de ayuda taiwanés en ALC. Se concluye que Taipéi tiene cierta influencia para contener el avance de China en la región, debido a su estatus de país democrático, su historia de desarrollo exitoso y, especialmente, sus fuertes vínculos con Washington. Sin embargo, frente a los renovados esfuerzos de China para imponer su política de "Una Sola China", las posibilidades de Taiwán de evitar el aislamiento diplomático siguen siendo inciertas.

P A L A B R A S C L A V E: Taiwán, ayuda exterior, América Latina y el Caribe, China, política de una sola China.

\section{R E S U M O}

Devido a que mais da metade dos países que reconhecem a Taiwan encontram-se em América Latina e o Caribe, Taipei e Pequim têm se esforçado em atingir reconhecimento diplomático na região, utilizando programas de ajuda ao desenvolvimento. Este artigo analisa as declarações dos funcionários governamentais e a literatura anterior, bem como os dados quantitativos da ajuda ao desenvolvimento, com o intuito de avaliar o impacto do programa de ajuda taiwanês em ALC. Conclui-se que Taipei tem certa influência para conter o avanço de China na região, devido a seu status de país democrático, sua história de desenvolvimento bem-sucedido e, especialmente, seus fortes vínculos com Washington. Entretanto, face os renovados esforços de China para impor sua política de "Uma China", as possibilidades de Taiwan de evitar o isolamento diplomático seguem sendo incertas.

PALAVRAS-CHAVE: Taiwan, ajuda exterior, América Latina e o Caribe, China, política de "Uma China". 


\section{N T R O D U C T I O N}

The topic of Taiwanese development assistance to Latin America and the Caribbean is strictly related to the topic of the Cross-Strait relations, since it has an impact on the decision of recipient countries to maintain diplomatic relations with Taipei. In fact, since the end of Chinese Civil War in 1949, Taiwan and China have been competing for diplomatic recognition in the international arena, and development aid has been a fundamental instrument of foreign policy for both the Republic of China (ROC, Taiwan) and the People's Republic of China (PRC, China). After Beijing replaced Taipei in the United Nations in 1971, Taiwan's struggle for recognition has become more intense, especially in Latin America and the Caribbean, where slightly more than half of those countries that maintains diplomatic ties with the Republic of China are located (as of June of 2019, nine out of seventeen). Despite being diplomatically isolated, since the 1970s and 1980s Taiwan has experienced an extraordinary economic growth (being one of the so-called "Four Asian Tigers"), becoming one of the world main exporters of manufactured products, and therefore accumulating large amount of foreign currency reserves (the sixth in the world according to IMF, 2019), which in turn enabled Taipei to use its economic advantages to pursue ambitious foreign aid programs. The primary goal of Taiwanese cooperation is to retain diplomatic recognition, but also breaking its isolation and maintaining the possibility to participate in a variety of international forums and multilateral organizations (especially those that do not require statehood, such as the International Civil Aviation Organization and the WHA/WHO) (Lu \& Hsiao, 2018). 
Taiwan represents a special case among the community of emerging donors, since its foreign aid policy is so strictly connected to its foreign policy strategy (Tubilewicz, 2016, p. 45), to the point that "the enhancement of international status has continually been the most important determinant in Taiwan's foreign aid policymaking” (Lin \& Lin, 2017).

Most authors generally agree that the delivery of development aid constitutes an effective instrument of public diplomacy. With this strategy, Taiwan could indefinitely trade development assistance with diplomatic recognition from small and micro-states (Wang, 2002, p. 99). This posture is especially evident within literature from the 1990s, when Taiwan indeed achieved increasing its international diplomatic recognition from 22 countries in 1988 to 30 by the mid-1990s (Hsieh, 1985; Lee, 1993; Lin, 1990; Cheng, 1994; Hickey, 1994; Lin, 1995; Wang, 1995; Wu, 1995; Lin, 1996; Moeller, 1996; Chan, 1997; Rubinstein, 1999; Lee, 2004; Liu, 2009).

Nevertheless, several authors also noted the geostrategic weaknesses of such an instrument of foreign policy (Cheng, 1994; Lee, 1994; Wu, 1995; Hsieh, 1996; Chan, 1997; Chen, 2002). In fact, Taiwanese development aid was unsuccessful in preventing the PRC's UN recognition and neither achieved preventing the continuous loss of diplomatic recognition from countries all around the world, nor was very successful in its efforts to be readmitted in international organizations (Hsieh, 1996, p. 104). Undoubtedly, ROC's diplomatic aspirations were frustrated by Beijing's plan to enforce the One China policy, on the one hand by using its increasing financial and commercial leverage, and on the other hand by focusing its development aid to countries likely to recognize Taiwan (Erikson \& Chen, 2007; Tubilewicz, 2007; Tubilewicz \& Guilloux, 2011). However, the emphasis on Taiwanese foreign aid as a diplomatic instrument has remained central, mostly linking ROC's aid to its foreign policy, and thus to Cross Strait relations.

This article is dedicated to the topic of Taiwan's foreign aid to Latin America and the Caribbean as connected to the issue of the diplomatic recognition of Taiwan by countries in the region. What is the impact of Taiwanese aid to Latin America and the Caribbean over its diplomatic recognition in the region, antagonized by the One China policy? Foreign aid, as a tool of foreign policy, may help Taipei to retain diplomatic recognition and avoid international isolation. Nevertheless, China's renewed efforts to encourage LAC countries to discontinue official ties with the ROC may prevail. 
To research this topic I will mostly use methods of qualitative nature (such as the analysis of declarations and statements by governmental officers and systematization previous literature), supported by quantitative data on Taiwanese aid flows when available. In the first section of this article, I will introduce the historical background of Taiwan and the Republic of China, such as European colonization of the island, the Japanese conquest, the establishment of the Republic of China, the Chinese civil war, the economic miracle, the process of democratization, etc. In the second section, I will offer a description of the antagonism between China and Taiwan for diplomatic recognition in Latin America and the Caribbean and the use of foreign aid as a foreign policy tool in the context of the "One China policy". Furthermore, I will evaluate the future possibilities for Taiwan in the region. In the third section, I will describe more in detail Taiwanese foreign aid and its policies, as well as providing an attempt to quantify the amounts and the number of projects directed to LAC region. I will describe potential developments for Taiwan's remaining diplomatic partners. As an anticipation, the article concludes that Taipei has indeed some means to gain leverage facing China's advancement in the region, due to its foreign aid program; its status of democratic country

upholding Western values and human rights; its successful history of development, and, especially, its strong ties with Washington. Nevertheless, its possibilities to avoid diplomatic isolation and to maintain its diplomatic relations in the region (especially regarding countries in the Caribbean) remain uncertain.

\section{Taiwan and the Republic of China: historical background}

Taiwan Island, also known as Formosa (from Portuguese Ilha Formosa) is an island in the Pacific Ocean, distant around $180 \mathrm{~km}$ from the SouthEastern coast of mainland China. Taiwan is a sizeable island, around four times the size of other islands like Jamaica, Puerto Rico or Cyprus, and about the same size as Costa Rica. Its interior is quite mountainous, reaching an altitude of 3,952 meters, and most the population of 23 million is concentrated in its coasts. Taiwan (as known as "Formosa and the Pescadores") also includes the Penghu or Pescadores Islands, an archipelago of 90 small islands in the Taiwan Strait, as well as Kinmen and Matsu islands, which are geographically described as being part of 
mainland China rather than Taiwan. Formosa island has been inhabited since its prehistory by aboriginal people of Malay-Austronesian origin, with few contacts with outsiders until the arrival of the Europeans in the XVI-XVII century. The Portuguese, the Spanish and the Dutch competed with local tribes for the control of the island until 1683, when Taiwan was formally annexed by the Chinese Qing Dynasty and a substantial Han Chinese immigration began. In 1887, Taiwan was upgraded to the status of Prefecture of the Chinese Empire, with its capital in Taipei. Subsequently, following the Chinese defeat in the First Sino-Japanese War (1894-1895), Taiwan was formally annexed to the Japanese Empire. Japanese colonization was instrumental to the island's modernization, industrialization and economic growth, together with the establishment of a formal sanitation and education system. During World War II Taiwan was bombed by the US as part of its operations against Japan, and in 1945, after Japanese Empire's surrender at the end of the war, 300.000 Japanese settlers were expelled by the island. Japan then renounced to the island, introducing the problem of the international legal status of Taiwan.

In the meanwhile, in 1912 (while Taiwan was still under Japanese rule), after over two thousand years of Imperial rule over China, the Republic of China was established, under the authoritarian control of the nationalist party Kuomintang (KMT) led by its founder Sun Yat-Sen. The KMT had to face numerous internal revolts, the Japanese invasion (1937-45), and, finally, the Chinese Civil War against Mao Zedong's Chinese Communist Party, fought intermittently between 1927 and 1949. The Republic of China took control of Taiwan from the Japanese in 1945, not without anti-government uprisings by local people, violently repressed by the KMT's Chinese Nationalists with thousands of victims. There were several incidents of repression such the "228 incident" in 1947, which gave the start to a period of assassination of dissidents known as "white terror" (Manthorpe, 2016, pp. 201-210).

After Mao's victory in mainland China and the establishment of the People's Republic of China in 1949, Chiang Kai-shek's Republic of China and the KMT retreated to Taiwan, together with two millions Chinese mainlanders, including business and intellectual elites, taking to Taipei a large amount of China's national treasures and most of its gold and foreign currency reserves. While the Republic of China continued claiming sovereignty over all of China, the Chinese Communist Party claimed that the ROC no longer existed and started to consider Taiwan as a rebel province. Both of them claimed to be China's legitimate government. 
The communist offensive to retake Taiwan continued until 1950, with the conquest of Hainan Island, Wanshan Islands and Zhoushan Island, but the start of the Korean War in the same year prevented further conflict between PRC and ROC. This event distracted Communist China's army and instigated the interposition of the US fleet in the Taiwan Strait as part of the American containment policy against the communist advancement. In fact, Mao privileged the Korean question over the Taiwanese question, which he initially considered a low priority "left-over issue" of the Chinese civil war (Friedman, 2007, p. 121).

Nevertheless, in the following years the Taiwanese question increased its relevance. On the one hand, the Sino-American Mutual Defense treaty between ROC and the US was signed in 1955. On the other hand, the slogan "we must liberate Taiwan" became central in Mao's Chinese popular sentiment campaign, aimed at driving the Chinese people to join his Great Leap Forward movement in 1958 (Friedman, 2007, p. 122). Subsequently, in Taiwan, ROC's leader Chiang Kai-Shek worked until his death (in 1975) to militarize and fortify the island, which was "transformed into an unsinkable aircraft carrier" of the anti-communist forces in East Asia (Tubilewicz, 2007, p. 26). The Kuomintang ruled Taiwan as an authoritarian one-party regime and established the martial law from 1949 to 1987 .

At the beginning, because of a widespread anticommunism, most countries in Latin America and the Caribbean sided with Taipei, which (with the approval of the US) was still holding Chinese seat in the UN Security Council. In 1971, following a rapprochement with Washington (due the common enmity with the Soviet Union), Chinese UN seat was assigned to Beijing, and thus most countries gradually switched their recognition to the PRC. In 1979 the United States finally also recognized the PRC, and discontinue their diplomatic ties with the ROC. Simultaneously, they approved the 1979 Taiwan Relations Act, which promotes a special (but non-diplomatic) relationship between the people of the United States and Taiwan.

On the economic level, in the 1960s, Taiwan (and the other Asian Tigers such as South Korea, Hong Kong and Singapore) was considered part of the underdeveloped world. In this phase, it is important to remember the contribution of US financial and economic aid to support the ROC in establishing its economic structure (Chang, 1965; Butterfield, 2004). In the following decades between the 1960s and the 1980s, Taiwan and other East Asian Countries were able to achieve an extraordinary 
economic growth, not only becoming an advanced industrialized country, but also achieving at the same time a reduction in income inequality. This phenomenon that has been known as the "East Asian Economic Miracle" is considered among the most important events in the global economic history (Thomas \& Stephens, 1994). In the decade of the 1980s, Taiwanese government decided to focus on innovating technology, starting a period of government-supported heavy investment in high technology and modernization (1981-1990). They invested, especially, in Research \& Development and computer components technology (monitors, desktops and motherboards). In the decade of the 1990s, Taiwan further focused on the information technologies and service economy. By the year 2000, Taiwanese companies were responsible for approximately $75 \%$ of the entire global production of computer motherboards (Kenney, 2004, p. 137). It is noteworthy to underline that such a rise as a global exporter has been achieved despite the lack of international diplomatic recognition. In 1989, in fact, only 5 percent of Taiwanese trade was directed to partners with official diplomatic relations with the ROC (Lee, 1993, p. 43).

Beyond trade, in the 1980s and the 1990s, Taiwan underwent as well severe social and political reforms, including a process of democratization which finally ended KMT authoritarian one-party rule in 1996 with the first democratic presidential elections. In the year 2000, the first non-Kuomintang (KMT) President was elected, Chen Shui-bian of the Democratic Progressive Party (DPP). Apart of free elections and an independent judiciary system, Taiwan's democracy is also reinforced by the strength of their civil society organizations and middle class activism. In terms of political freedom, Taiwan is ranked as the second freest country in Asia after Japan (with a score of 93 out of 100) (Freedom House, 2018).

Today, Taiwanese politics continue being polarized over the issue of the relations with China. On the one hand, the KMT, leading the PanBlue coalition, supporting the status quo and still favoring the possibility of a reunification with the mainland. On the other hand, the Democratic Progressive Party-DPP-, leading the pan-green Coalition, eventually desiring an official declaration of independence, even though, in practice, it also supports the status quo because it cannot afford the risk of provoking a reaction from China.

Nowadays, 176 countries in the world hold diplomatic relations with Beijing, while Taiwan, considered by Beijing a nonaligned province, only retains full diplomatic relations with 17 countries, as well as embassies, trade agreements and foreign aid programs. Furthermore, the ROC 
maintains non-official diplomatic relations with the EU and with dozens of states that recognize the PRC through de facto embassies. These institutions are named alternatively Taipei Economic and Cultural Representative Office (TECRO), Taipei Economic and Cultural Office (TECO), Taipei Representative Office (TRO), among others. Those offices perform regular consular activities (e.g. visas and passports issuance) as well as promoting "bilateral trade, investment, culture, science and technology exchanges and cooperation, as well as better understanding" (Ministry of Foreign Affairs, 2019).

\section{Taiwan-China competition for Latin America and the One-China policy}

Originating from the end of the Chinese civil war, the so-called "One China policy" is a cornerstone of PRC's foreign policy relations. It consists in the acknowledgment that only one China exists and, as a consequence, other countries must recognize only one Chinese government and cannot establish diplomatic relations with both the People's Republic of China and the Republic of China. The One-China policy is particularly relevant for Latin America and the Caribbean since the region is the epicenter of the diplomatic struggle between China and Taiwan. In fact, the slight majority of countries holding Taiwanese recognition (nine out of seventeen, as shown by Table 1 below) is located in this region, and particularly in Central America, which sustain this arrangement because Taiwan spends heavily to maintain it. As a response, since the 1980s, China also strengthened its so-called "checkbook diplomacy", offering aid, loans and investment to Taiwan's diplomatic allies. This is a sort of a "bidding war" in which offers of foreign assistance by both sides escalated (Brautigam, 2010, p.11; Rich, 2009). This strategy has been evident in LAC, where both China and Taiwan invested in costly projects, sometimes in exchange for ending diplomatic relations with the other party.

However, Taiwan can difficultly outspend mainland China, which admittedly uses the aid to impose its "One China policy", rewarding countries that do not recognize Taiwan as a separate country. (Taylor, 1998; Brautigam, 2008; Rich, 2009). In fact, as openly specified as one of the four "goals" of Chinese official policy toward Latin America and the Caribbean: 
Table 1. Countries recognizing the PRC or the ROC in Latin America and the Caribbean in July 2019

\begin{tabular}{|c|c|c|}
\hline & $\begin{array}{l}\text { Countries recognizing } \\
\text { the PRC (China) }\end{array}$ & $\begin{array}{l}\text { Countries recognizing } \\
\text { the ROC (Taiwan) }\end{array}$ \\
\hline $\begin{array}{l}\text { Central } \\
\text { America }\end{array}$ & $\begin{array}{c}\text { México, Costa Rica, El Salvador, } \\
\text { Panamá }\end{array}$ & $\begin{array}{c}\text { Belize (1989), Guatemala (1993), } \\
\text { Honduras (1941), Nicaragua (1962- } \\
1985 ; 1990)\end{array}$ \\
\hline Caribbean & $\begin{array}{l}\text { Antigua \& Barbuda, Bahamas, } \\
\text { Barbados, Cuba, Dominica, } \\
\text { Dominican Republic, Grenada, } \\
\text { Guyana, Jamaica, Suriname, } \\
\text { Trinidad \& Tobago }\end{array}$ & $\begin{array}{c}\text { Haití (1956), St. Kitts \& Nevis (1983), } \\
\text { St. Lucía (1984-1997; 2007), St. } \\
\text { Vincent \& the Grenadines (1981) }\end{array}$ \\
\hline $\begin{array}{l}\text { South } \\
\text { America }\end{array}$ & $\begin{array}{c}\text { Argentina, Bolivia, Brazil, Chile, } \\
\text { Colombia, Ecuador, Perú, Uruguay, } \\
\text { Venezuela }\end{array}$ & Paraguay (1957) \\
\hline
\end{tabular}

Source: Compiled by the author based on information from the Ministry of Foreign Relations of the Republic of China (Taiwan) website: http://www.mofa.gov. $\mathrm{tw} /$

The one China principle is the political basis for the establishment and development of relations between China and Latin American and Caribbean countries and regional organizations. The overwhelming majority of countries in the region are committed to the one China policy and the position of supporting China's reunification and not having official ties or contacts with Taiwan. The Chinese Government appreciates such a stance. China is ready to establish and develop stateto-state relations with all Latin American and Caribbean countries based on the one China principle. (China's Policy Paper on Latin America and the Caribbean, 2008)

Historically, nevertheless, China had a difficult time to establish diplomatic relations with LAC countries. In the $1950 \mathrm{~s}$ and $1960 \mathrm{~s}$, due to the widespread anticommunism among LAC governments, only La Havana recognized the PRC (and even its relationship with Cuba was not easy due to Castro's close ties with the URSS). In this period, the competition with the mainland and the One-China policy prompted the beginning of Taiwan's foreign aid program as a tool of public diplomacy (Hsieh 1985, p. 210; Lin, 1990, p. 151). Initially, Taiwan sought diplomatic recognition from the newly-decolonized states (in Africa and elsewhere) in order to gather 
support for the Taiwanese cause, facing Beijing's impending bid for UN membership (Hsieh, 1985, p. 171).

Following Washington's rapprochement with Beijing in the 1970s and the subsequent acceptance of Beijing's UN membership claims, ${ }^{1}$ China adopted a more pragmatic stance in LAC region. Several military and authoritarian regimes became closer to China as a way to contrast Soviet influence. During the 1970s, Chile, Peru, Ecuador, Mexico, Argentina, Guyana, Jamaica, Trinidad and Tobago, Venezuela, Brazil, Suriname, Barbados, in chronological order, recognized the PRC. They were followed in the 1980s by Colombia, Antigua, Bolivia, Grenada, Nicaragua, and Uruguay. In 1988, Taiwan created the Overseas Economic Cooperation and Development Fund (renamed the International Economic Cooperation and International Development Fund in 1991). Through the delivery of financial (loans and concessional loans) and technical aid (mostly in the primary sector), Taiwan achieved in the following years official diplomatic recognition by several Caribbean nations (Saint Vincent and the Grenadines, Dominica, Saint Kitts and Nevis, Saint Lucia, the Bahamas, Grenada, Belize and Nicaragua). Belize established diplomatic ties with the PRC between 1987 and 1989, but when it adopted a "TwoChinas policy" (recognizing China and Taiwan as separate independent states and establishing diplomatic ties with both of them), Beijing rescinded its diplomatic relations with Belmopan.

Following Taiwan's economic flourishing at the beginning of the 1990s, several important PRC's diplomatic allies in LAC (e.g. Argentina, Bolivia, Brazil, Chile, and Mexico) opened in Taipei their respective "commercial representative offices". Taipei started to participate from 1991 in the Summits of Central American Countries and encouraged Taiwanese enterprises to invest in the region to consolidate its political ties. After Taipei deposited 150 million USD into the Central American Bank for Economic Integration, Taiwan's Central American allies supported its (unsuccessful) petition for ROC's return to the UN in 1993 (Esteban, 2007). In 1998, Taipei created the Aid Fund for the Development of Central America and, in the following years, it strengthened its

1 In Latin America and the Caribbean, six countries (Chile, Cuba, Ecuador, México, Perú, and Trinidad and Tobago) voted in favor of United Nations General Assembly Resolutions 2758 of 1971 on the subject of the "Restoration of the lawful rights of the People's Republic of China in the United Nations”, four abstained (Argentina, Colombia, Jamaica and Panamá) and ten voted against (Bolivia, Brazil, Costa Rica, Dominican Republic, El Salvador, Guatemala, Haití, Honduras, Nicaragua, Paraguay). 
cooperation with Paraguay, its strongest diplomatic allied in South America. Furthermore, in 2006, it created the program "Study in Taiwan" to enhance the cultural and academic exchange with the region. As it can be noted, Taipei has taken the opportunity to create ties with smaller countries which are more in need of development assistance. Larger countries with higher international projection, in contrast, have a preference for the commercial and economic ties that Beijing can offer (Li, 2005; Esteban, 2007). To counteract Taiwanese action, since 1997 Beijing has established the delivery of several aid packages to Central America and the Caribbean, which were followed by a change in recognition from Bahamas and Saint Lucia (1997, switching back to ROC in 2007), Dominica (2004) and Grenada (2005). When Costa Rica changed its recognition status to the PRC in 2007, China provided an extremely generous aid package that included a new soccer stadium (83 million USD), the purchase of government bonds (300 million USD), the construction of a highway and other public works, a joint venture to develop the national petroleum refinery ( 1 billion USD), and a facilitated access to PRC markets for Costa Rican coffee and other products (Ellis, 2011, p. 89).

In 2008, China and Taiwan agreed a sort of "diplomatic truce", deciding to stop the use of financial incentives to achieve diplomatic recognition from each other's diplomatic allies (Koleski \& Blivas, 2018, p.18). Nevertheless, following Tsai Ing-Wen election as President of the ROC in 2016, Beijing "suspended contact with their Taiwanese counterparts because the island's new leader would not endorse the idea of a single Chinese nation” (Hernández, 2016). Subsequently, Beijing renewed its efforts to diplomatically isolate Taiwan. Since then, six countries ceased recognition of the ROC (three in LAC). In June 2017, in a major success for Chinese foreign relations, Panama (the most important partner country for Taipei in Central America, with diplomatic relations with the ROC since 1922), switched recognition to the PRC. China, in fact, is the second greatest user of its channel, given that "an estimated 40 percent of all traffic going through the canal is tied to China in one way or another" (Ellis, 2009, p. 227). Recognition by Panama is in line with the hypothesis that countries with higher socioeconomic development tend to recognize Beijing because they can benefit in a greater level from trade and financial relationship with the PRC. Finally, El Salvador (after Taipei refused to donate an "astronomical amount" of financial aid requested by San Salvador) and Dominican Republic (encouraged by loans and investments by Beijing amounting to US\$3.1 billion) have been the latest countries in 
establishing relations with the Beijing, ceasing relations with the ROC in 2018 (see Table 1 above). In conclusion, Beijing's decision to invest more resources into LAC region (in terms of development aid, investments, and trade relations) could prompt the remaining nine Taiwanese political allies to switch recognition in favor of China. Chinese authorities have been cautious in this respect, largely due to the possible repercussions over its relations with the United States. However, in the last two decades Beijing assumed more active stance and achieved several major diplomatic accomplishments, among which the most important is the recognition by Panama. China's commitment to extend its Belt and Road Initiative to $\mathrm{LAC}$ region indicates that Beijing will continue to dedicate resources to expand its influence in the region and, possibly, attract Taiwan's diplomatic partners.

\section{Taiwan's aid program and its projection towards Latin America and the Caribbean}

The International Cooperation and Development Fund (ICDF), (財團法人國際合作 發展基金會 in traditional Chinese), located in Shilin District in Taipei, is the principal Taiwanese government agency responsible of development aid programs and their relative planning, executing, and monitoring. It is on behalf of the Ministry of Foreign Affairs -MOFA- as well as conducting its own independently funded technical assistance programs Taiwanese foreign aid programs began in 1959, with the deployment to Vietnam and to decolonized African nations (the so called "Operation Vanguard") of agriculture experts to offer technical assistance to increase crop production. In 1962, the initial African task force was extended into the Sino-Africa Technical Cooperation Committee, merged into the Committee of International Technical Cooperation -CITC- in 1972. Following Taiwanese exceptional economic growth, the International Economic Cooperation Development Fund -IECDF- was created in 1989 with the objective of providing foreign economic assistance. With the multiplication of development projects, in 1996, ROC government created the ICDF as an independent organization, incorporating both IECDF and CITC (Her, 2012) as a key instrument for Taiwanese outreach to its diplomatic partners in the developing world (ICDF, 2010). The removal of "economic" from the 
name of the agency reflects MOFA's preference to consider development aid as a means to serve ROC's diplomacy (rather than economic) interests (Tubilewicz, 2016, p. 50).

ICDF mission is "promoting humanitarianism, economic progress and sustainable development while advancing Taiwan's diplomatic interests. To do so, the agency focuses on technical cooperation, human resources development, humanitarian assistance, lending and investment, overseas volunteers and overseas youth services" (Her, 2012). The ICDF identifies four core operations: "lending and investment, technical cooperation, humanitarian assistance, and international education and training" as well as to offer "provide aid in the event of natural disasters or international refugee crises (ICDF, 2019). To ensure its aid effectiveness, the ICDF has established key performance indicators to assess project outputs, outcomes and impacts" (ICDF former secretary-general Tao, quoted in Her, 2012).

As the Ministry of Foreign Affairs -MOFA- claims in its "Foreign Policy Guidelines", Taiwan efforts are directed at "implementing policies that enhance Taiwan's prosperity and promoting foreign relations that strengthen the international status of the ROC" as well as in "making concrete contributions to the global community, and enhancing its international profile through economic and humanitarian air policies" (Ministry of Foreign Affairs, 2016). Such policies include not only governmental bilateral assistance, such as grants and in-kind contributions, but also cooperation provided through international non-governmental organization (e.g. the Pan American Development Foundation - PADF), and civil society organizations, corporate donors and individual citizens (Lin \& Lin, 2017).

Due to its development experience (and the fact that it achieved an extensive economic growth in spite of being located in an area prone to earthquakes, typhoons and other natural disasters), Taiwan claims to have the ability to provide help, inspiration, empathy and cooperation over issues of development, recovery and resilience that its partners are facing. Data from the PADF and the ICDF shows that the communities that received Taiwanese aid have largely benefitted from it, in terms of increased agricultural outputs and improved food security, incomes generation, increased resilience and recovery from natural disasters (PADF, 2016; ICDF, 2019). These aid programs offer a value for those recipient countries that is convincing enough to maintain ties with Taipei in spite of Beijing's pressure. 


\section{Quantifying Taiwanese aid}

In recent years, Taiwanese foreign aid reached considerable levels, amounting its total budget to 438 million USD in 2010, 332 million in 2012, 299 million in 2013 and 290 million in 2015 (there is no data on the total aid budget after 2015) (MOFA, as cited in Harold, Morris \& Ma, 2019). In Figure 1 below, in order to represent the relative importance of the region in the respective aid program of each donor, I show the percentage of their total Official Development Aid -ODA- budget that is allocated to Latin America and the Caribbean from a variety of donors. In this graph, I compare the amounts of aid allocated by Taiwan with allocation by China, the United States of America, Germany, Japan, Spain and the average donor member of the OECD's Development Assistance Committee, divided by historical phases (following Maggiorelli, 2017). Unfortunately, I don't have sufficient data for Taiwan to be able to disaggregate Taiwanese total aid budget by region in the last phase (after 2006), since it is deemed to be confidential by the Taiwanese MOFA. As it can be observed, Taiwan has historically dedicated between $30 \%$ and $50 \%$ of its budget to LAC region, second only to Spain (which is providing between 40 to 60 percent of its budget to this region). That happens despite the fact that Taipei doesn't have a great economic or cultural interest in the region. Japan does not particularly focus on LAC, allocating less than $5 \%$ of its aid budget to the region, while China has increased its focus on LAC in the recent phase, increasing its aid allocation to the region to more than $15 \%$ of its total aid budget. From this graph, is evident the greater relative importance of LAC region for China and Taiwan as compared to the other donors (except Spain), despite their geographical distance.

Coming to the composition of Taiwanese foreign aid to Latin America and the Caribbean, most of its aid (up to 90\%) is provided in the form of direct assistance. The rest is composed by aid channeled through the ICDF (around 8-9) and the rest is transferred to international non-governmental organizations (Harold, Morris \& Ma, 2019). Unfortunately, the itemized details of Taiwanese aid are deemed confidential by Taiwanese MOFA and are thus unavailable.

For instance, Taiwanese development assistance has been particularly significant to Caribbean states that otherwise would not have been economically self-sufficient, being Taiwan their principal donor. For example, in the case of Republic of Haiti, Taiwanese foreign aid has equaled in several years a fifth of the Haitian government's annual budget 


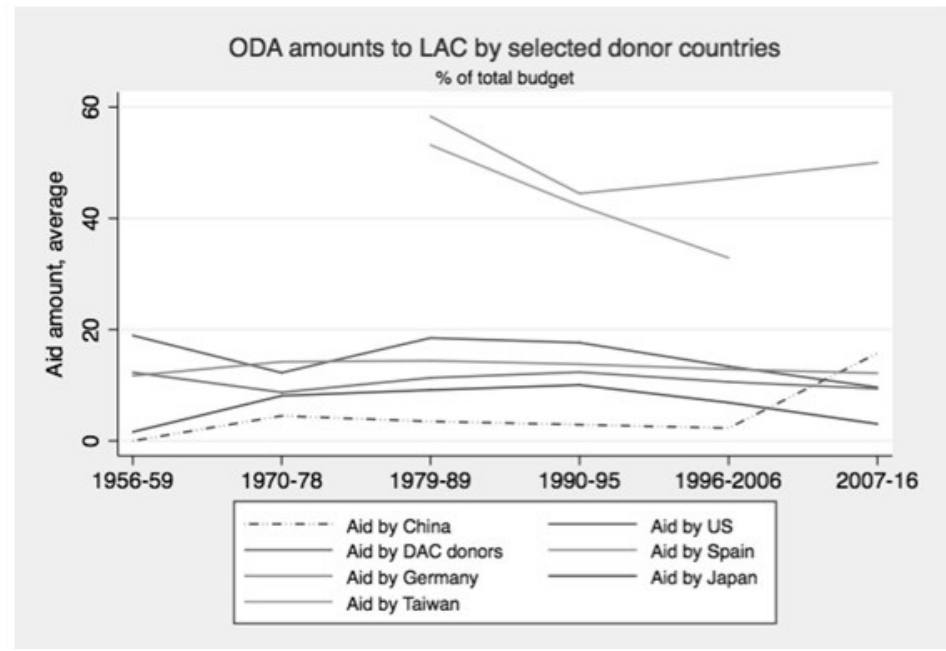

Figure 1. ODA amounts to LAC by selected donor countries

Note: no data available for China for phase 4 (1990-1995) and for Taiwan for phase 6 (2007-2016).

Source: Compiled by the author based on data from Bartke (1989), CIA (19751984), OECD (1987, 2017), AidData (2017) and Dreher \& Fuchs (2012).

(Rich, 2010). In the case of Honduras, Taiwan reportedly conceded since 2006 more than 205 million USD in loans and \$27 million in grants, as well as donating a private jet to be used as the president's official airplane (Menchu, 2017). In Guatemala, is funding a 680 million USD four-lane freeway to Puerto Barrios, for which Taipei will provide 250 million USD in grants and 350 million USD in loans. In the case of Belize, as well as owning $10 \%$ of its external debt, Taiwan also signed a 60 million USD cooperation agreement, which includes 20 million USD in grants and 40 million in loan financing.

Latin America and the Caribbean are largest recipients of ICDF projects, amounting to more than 152 million USD over the past 15 years (Harold, Morris \& Ma, 2019). As shown in Figure 2 below, the ICDF officially implemented 180 projects in 10 LAC countries: 95 in Central America (of which 33 under implementation), 64 in the Caribbean (of which 21 under completion) and 21 in South America (8 currently being implemented). 


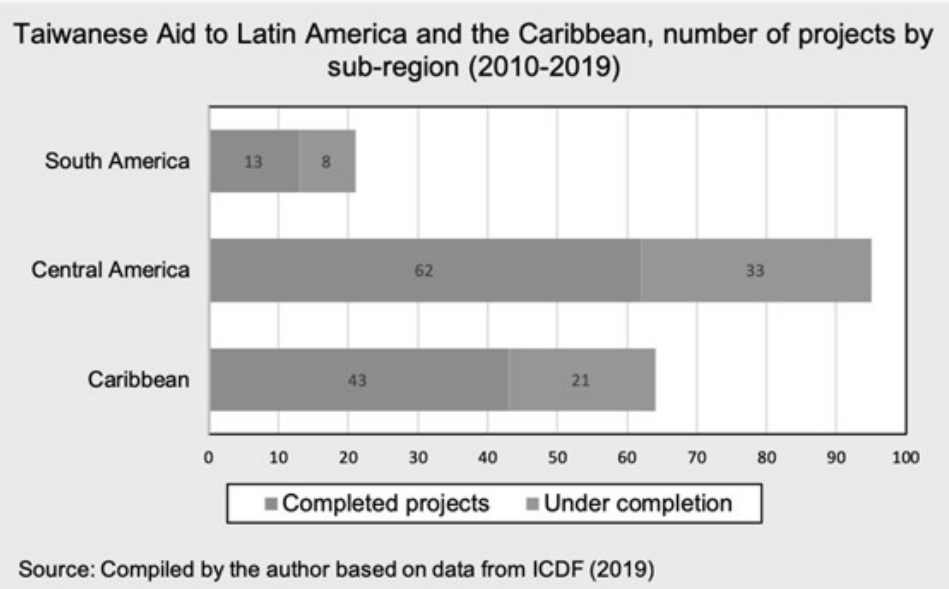

Figure 2. Taiwanese aid to Latin America and the Caribbean, number of projects by sub-region, 2010-2019

As displayed in Figure 3 below, Honduras, with 29 projects, is the major recipient of Taiwanese development assistance projects, followed by Haiti ( 25 projects) and Nicaragua and Guatemala (23 projects each). As can be observed in Figure, Taiwan concentrates its cooperation efforts into the countries with whom it maintains official diplomatic ties, being Ecuador the only country in LAC which is receiving aid from Taiwan despite recognizing the PRC.

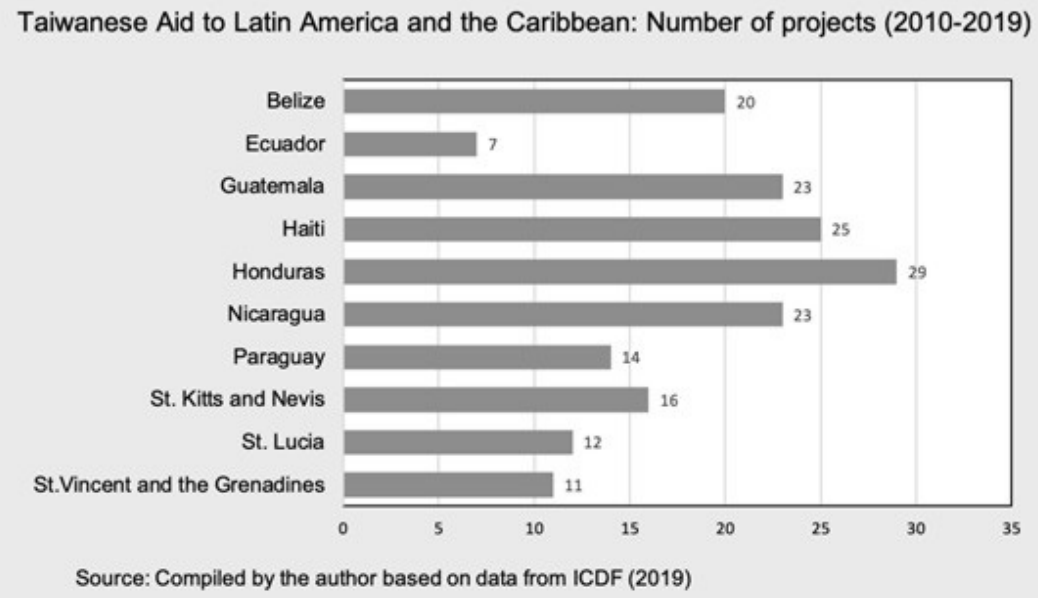

Figure 3. Taiwanese aid to Latin America and the Caribbean: number of projects, 2010-2019 
It has also to be noted that in the official information reported by the ICDF in 2019, data relative to countries that recently withdrew their recognition of the ROC appears to have been removed. That is the case of Panama, El Salvador and the Dominican Republic. Nevertheless, in older reports we can find that Taiwan had indeed several projects active in those countries as well. For example, in 2017, there were two active technical assistance projects in Panama, 12 active projects in El Salvador (10 technical assistance, 2 lending), and 5 technical assistance projects in Dominican Republic (ICDF, 2017, pp. 97-98), which today result as completed projects. Following San Salvador decision to toughen diplomatic ties, Taipei has transferred six of its aid programs (of which four were dedicated to agricultural and aquaculture technologies) from El Salvador to Nicaragua. This last country hosts now the largest Taiwanese team and manages a budget of around 3 million USD (Hsu, 2018). The fact that Taiwan redirected its programs to another country when El Salvador made stricter its official diplomatic ties is a further indication that foreign aid is chiefly important for Taiwan as a foreign policy tool (rather than being moved by purely humanitarian motives). In this sense, it is also imperative to remember the pressure against working with the ICDF that is coming from China in countries that recognize the PRC. In some cases (such as Turkey and Egypt, mentioned by Lee, 1993, p. 53), this pressure has been prompted to reject substantial aid offers by Taiwan. In these countries, Taiwan admittedly prefers to "collaborate with them through international organizations or international non-governmental organization to overcome this situation" (ICDF Deputy Secretary-General Lee Pai-po, as quoted in Herrera, 2019).

IDCF operations can be categorized in four specific areas of intervention: (1) lending and investment, (2) technical cooperation, (3) humanitarian assistance, and (4) international education and training (ICDF, 2019). As shown in Figure 2 below, of the 180 projects within these ten countries, technical cooperation is the main modality of ICDF projects in LAC (104 projects), followed by humanitarian assistance (44 projects), Lending and Investment (23 projects), International Education and Training ( 7 projects) and uncategorized projects ( 2 projects).

The large and increasing share of technical cooperation projects (57\% of the total) reflects Taiwanese awareness of the importance to coordinate with and involve the recipient in the transfer of expertise, in contrast with lending and investment which is a more direct form of aid. This emphasis on technical cooperation differs from the PRC, which underscores infrastructural development. 


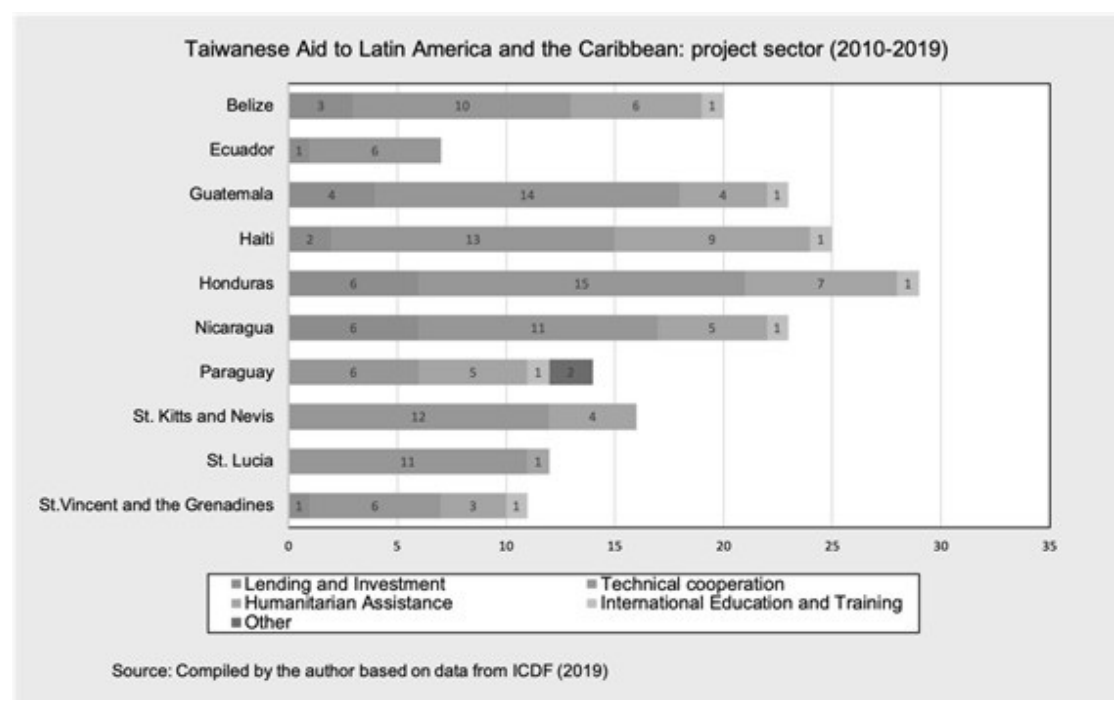

Figure 4. Taiwanese aid to Latin America and the Caribbean: project sector, 2010-2019

In Latin America, Taiwanese aid reflect the need of these countries of investment in strategic national industries such as support to agricultural productivity, microfinance to foster small and medium enterprises, information technology, health, etc. In the Caribbean, which has a narrower economic base than Latin America (Nicholson, 2015; Morgan, 2017), Taiwan support is directed mostly to agriculture and tourism (industries highly vulnerable to climate change). In summary, through ICDF programs, Taiwan helped several partner nations in the LAC region. Among other development outcomes, ROC assisted local communities to improve farming outcomes and ensure greater resistance to vulnerability, preparing for and recovering from natural disasters and crop disease.

What remains to be understood is how far Taiwanese aid programs could influence recipient governments in their diplomatic recognition decisions, avoiding the trap of being continuously threatened to be abandoned in favor of China. That is a permanent risk due the fact that LAC countries could pressure the ROC in order to extract more resources, grants and loans to maintain diplomatic ties.

\section{Means of leverage vis-à-vis the PRC}

Taiwanese aid to Latin American and the Caribbean countries, as a tool of foreign policy, is supported by other means of leverage: Taiwanese trade 
and investment; their common identity as democratic nations; Taipei's participation in regional organizations; LAC historical ties with United States (the main sponsor of Taiwan in the region), which could give Taiwan an advantage as compared to China.

Trade means only has a relative importance: even if the total bilateral trade volume with LAC countries has been over 12 billion USD in 2018, it only represents $2 \%$ of total Taiwanese trade (as shown in Figure 5 below). That is well below trade levels from the PRC (which totaled $\$ 306$ billion in 2018). Taiwan's biggest partner in the region is Brazil (totaling US $\$ 3.86$ billion in trade and US $\$ 500$ million in investments in 2017), followed by Mexico (US $\$ 2.96$ billion in trade and US $\$ 1.1$ billion in investment in 2017) and Chile (US\$1.61 billion in trade and US $\$ 14$ million in investment). In fact, the vast majority of bilateral trade is happening with countries which do not hold formal diplomatic relations with the ROC. However several LAC countries that recognize Taiwan have established with the ROC Free Trade Agreements and Economic Cooperation Agreements, such as Panama (coming into effect as January, 2004), Guatemala (July 2006), Nicaragua (January 2008), El Salvador (March 2008), Honduras (July 2008) and Paraguay (signed in July 2017, not yet in effect as June of 2019). Furthermore, the economic relationship with the ROC has a particular importance for the ICT industry, with substantial investments by Taiwanese enterprises such as Foxconn, Asus, Compal Electronics, Acer, Braview, New Kinpo, ADATA, Advantech, Delta, Portwell, Askey, Pegatron, etc. (MOEA, 2019).

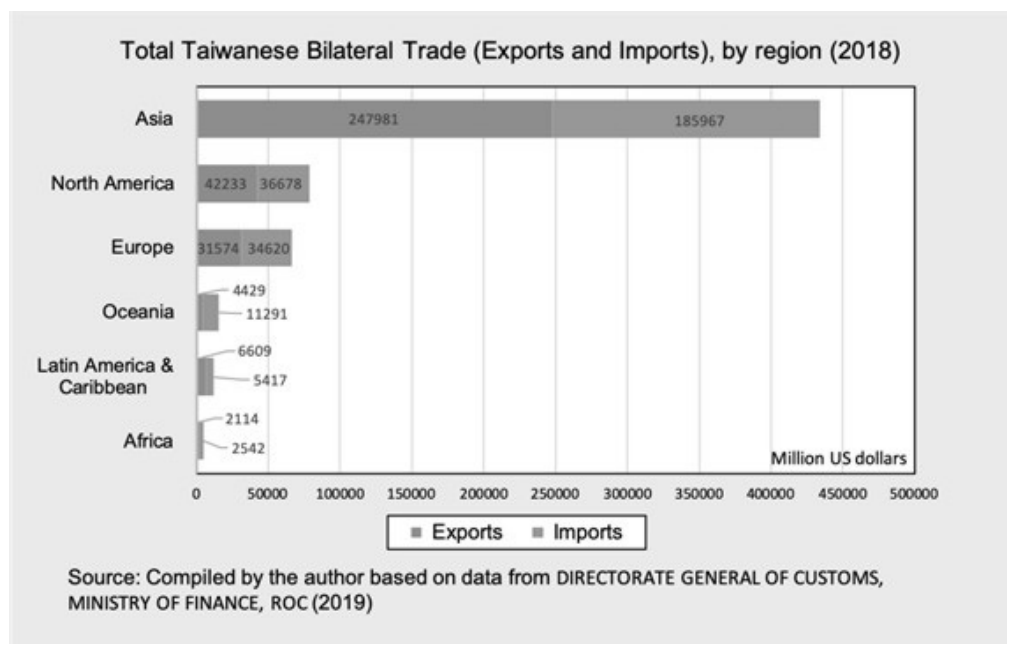

Figure 5. Total Taiwanese Bilateral Trade (Exports and Imports), by region, 2018 
Recent literature underlined how the increase or potential increase in trade with the PRC may explain LAC countries decision to switch recognition, arguing that foreign aid is not effective as "a primary method in maintaining allies" (Rich \& Dahmer, 2018). Consequently, LAC countries and especially the Caribbean states (due to their lack natural resources and limited potential for economic growth) can expect to be actively courted by Beijing.

A second means of leverage that is often mentioned in previous literature is Taipei's ability "to embed itself and in some cases create regional institutions" (Rich \& Dahmer, 2017). In fact, through its financial assistance, Taiwan has sustained political integration projects in LAC, such as the Sistema de Integración Centroamericano-SICA- and the Secretaria de Integración Económica Centroamericana-SIECA- (SICA's economic wing), becoming its main donor. This project includes assistance in the construction of the building that houses its secretariat. Furthermore, Taiwan coordinates its aid programs with SICA. Additionally, since 1992, Taiwan is an extra-regional partner country of the Central American Bank for Economic Integration (Banco Centroamericano de Integración Económica, BCIE), contributing US $\$ 150$ million to the bank. Moreover, Taiwan is an allied of several regional developmental banks, such as the Inter-American Development Bank -IADB- (Rich \& Dahmer, 2017).

Third, some authors consider Taiwan's positive image in LAC as a very important factor to build durable support (Alexander, 2014). In their view, Taiwan has demonstrated a trajectory of international solidarity and shared values such as democracy and respect of human rights. On the one hand, it is true that Taiwan is ranked very highly in terms of political freedom, following Japan as the second freest country in Asia. Furthermore, Taiwan has achieved a better score than established Western democracies such as France and Italy (Freedom House, 2018). On the other hand, nevertheless, countries with formal ties with the ROC in the region present a mixed democracy record. While four of its partners (Belize, St. Kitts \& Nevis, St. Lucia and St. Vincent \& the Grenadines) are ranked as free countries, five of them (Guatemala, Honduras, Nicaragua, Haiti and Paraguay) are ranked as only "partly free" by the Freedom House. The same mixed record results from the observation of corruption rankings. Out of nine partners of Taiwan in the region, the same five "partly free" countries (Guatemala, Honduras, Nicaragua, Haiti and Paraguay) also scored below the world median in the 2018 Corruption Perception Index (Transparency International, 2019). Only two partners 
are ranked above the median (St. Lucia and St. Vincent \& the Grenadines; Belize and St. Kitts \& Nevis are not ranked by TI). Furthermore, in an evidently contradictory fashion for a regime proud of democracy, human rights and liberal values, ROC bilateral aid has also been linked to cases of corruption in the region. For example, the former President of Guatemala Alfonso Portillo admitted in court in 2014 to have received bribes from Taiwan for 2.5 million USD in exchange for diplomatic recognition. The former president of El Salvador Francisco Flores was charged for the disappearance of 10 million USD in donations from Taiwan directed to 2001 earthquake's victims (Malkin, 2017).

Finally, perhaps the most important means of leverage that Taiwan can use vis-à-vis China seems to be the pressure that the US can put on its current and potential diplomatic allies. In fact, US officials have confidentially tried to dissuade LAC countries to terminate their diplomatic recognition of Taiwan. Following Panama's recognition of Beijing, US publicly proclaimed the importance for all concerned parts to "to engage in productive dialogue and to avoid escalatory or destabilizing moves", calling for resumption of cross-strait talks (Chiang \& Hsu, 2018), and hailing Taiwan as be "a vital partner, a democratic success story and a force for good in the world" that deserves US strong support (Katina Adams, spokeswoman for the US Department of State's Bureau of East Asian and Pacific Affairs, as quoted in Lu \& Hsiao, 2017). The US supported Taiwan regarding also El Salvador recognition switch. The White House Press Secretary voiced the Washington's "grave concern" and stated that the pro-Beijing diplomatic choice would result in "a reevaluation of our relationship with El Salvador" (Statement from the Press Secretary on El Salvador, 2018). In an unprecedented move, the US recalled its diplomats to the Dominican Republic, El Salvador, and Panama "for consultations related to recent decisions to no longer recognize Taiwan". The US expressed "concern over the rising number of countries that have cut diplomatic ties with Taiwan in favor of China", warning that China's economic stimuli to countries switching recognition to Beijing would "facilitate economic dependency and domination, not partnership" (Beech, 2018). In addition, Washington menaced to reduce "U.S. foreign aid for those countries that downgrade relations with Taiwan" (Sullivan \& Lum, 2018, p. 2.). For Taiwan, highlighting the importance of a containment strategy towards the PRC would play in line with Washington's preferences. This could be supplemented by an increase of economic links with US, providing incentives to regional partners to continue recognizing 
the ROC. By providing information, technical assistance, and governancestrengthening initiatives, the United States could limit the increase of unwelcome by-products of China's engagement in Latin America, (such as economic displacement, corruption, and organized crime) (Ellis, 2018b).

\section{Potential developments}

The advance of PRC in the region has raised the question of who, among Taiwan's remaining partners, will be the next in rescinding diplomatic relations with Taipei, attracted by the benefits associated with the recognition of Beijing. Outside the strict circle of politicians and negotiators of such option, it is difficult to know with certainty. Nevertheless, it is clear that all Taipei's diplomatic partners are at least considering the possibility, evaluating the benefits and the risks associated with a switch in their diplomatic stance. Possibly, the hard stance of the US regarding the change of recognition of Panama, the Dominican Republic and El Salvador led other countries in LAC to delay a decision on the subject. In all remaining partners there are actors (such as politicians, businessmen, etc.) who are enticed by the prospects of increased business opportunities with Beijing. Meanwhile, others oppose furthering the relations with the mainland because of the increased competition by Chinese products for local manufacturers. They also stress the risks associated with the betrayal of loyalty towards Taiwan and the US, and the estrangement from values such as democracy and human right that such a move would entail (Ellis, 2018a).

In Paraguay, current president Mario Abdo Benitez seems inclined to maintain its ties with Taiwan. He was able to negotiate an agreement with Taipei to redouble its aid commitments during his presidency as compared to the money received by his predecessor (reaching the sum of 150 million USD during five years). Nevertheless, China is potentially a very important market for Paraguay's agricultural produce, especially soy beans, as evidenced by the presence in Paraguay of Chinese firm COFCO (China Oilseeds and Foodstuffs Corporation) (Ellis, 2018a).

In Nicaragua, Sandinista government's relations with Taiwan are apparently stable. In 1979 when the Sandinista Front arrived to the power, Daniel Ortega switched his country's recognition from Taipei to Beijing. However, in 1995, during Violeta Chamorro's presidency, Nicaragua returned to the Republic of China. Before returning to the presidency, Ortega threatened restore relations with the People's Republic of China. But finally, after his reelection in 2007, he stated that Nicaragua did not 
recognize the One China Policy and decided to maintain diplomatic relations with the Republic of China. Nevertheless, as part of his strategy to diversify economic and trade relations, Ortega is trying to play both sides, courting the People's Republic of China without upsetting his country's relations with Taiwan, with whom he established a free trade agreement. For example, in an attempt to establish direct trade relations with China (nowadays Nicaragua is buying Chinese products through Panama, the US, Costa Rica and Mexico), Managua hosted "ExpoChina" trade show in 2010 (Rogers, 2010). However, in February 2019, Ortega accepted a US $\$ 100$ million loan offered by Taiwan (Herrera, 2019). Thus, for the moment "there is no indication that Ortega plans to change the status quo with respect to Taiwan" (Ellis, 2018a). Regarding Belize, the position of Belmopan also seems to be firm, with Taiwanese President Tsai paying a visit in August 2018. While Taiwan is continuing to provide substantial aid to Belize, there is some discontent because Taiwan is providing much more aid to its neighboring and rival country, Guatemala (Ramos, 2017). Regarding the latter, Guatemala's relations with Taipei is more uncertain: despite the great amounts of aid received by Taiwan, Guatemala's officials also expressed an interest in the potential benefits from a formal relationship with China. Moreover, given the internal political instability, President Jimmy Morales may elude Western pressures (and possible sanctions) by turning to Beijing. In Honduras, as well, political instability may lead Juan Orlando Hernandez to approach the PRC, a partner that doesn't interfere with internal affairs such as criminal activities, human rights violations or the prosecution of political oppositions (Ellis, 2018a).

In El Salvador, on the contrary, the situation seems to be turning again in favor of Taipei. El Salvador's President-elect Nayib Bukele, willing to renovate a positive relationship with Washington (possibly hurt by El Salvador's turn to Beijing), is considering the possibility to reverse the decision to switch recognition from Taiwan to China, since such decision benefitted only the outgoing government. As Bukele put it, "China does not play by the rules; they do not respect the rules". He criticized Chinese development packages because "they develop projects that are not feasible, leaving countries with huge debt that cannot be paid back and use that as financial leverage" (Gao, 2019). Nevertheless, "that decision has not been taken”, as of March 14, 2019 (Yeh, 2019). As an indicator of the uncertainty, Beijing has not formally opened its embassy in San Salvador and it is still operating from the Sheraton Hotel in the country's capital. 
In the Caribbean, the situation is even more unpredictable than in Central and South America, since smaller countries are much more susceptible to the "dollar diplomacy" of Beijing and Taipei. In Haiti, Taiwan has provided substantial development aid and it is supporting Jovenel Moise's government, although there is some discontent for the delay in the delivery of a 150 million USD loan promised by Taiwan when Moise travelled to Taipei. The tiny nations of the Lesser Antilles (St. Vincent, St. Lucia, and St. Kitts and Nevis) seem to maintain good relations with Taiwan, even though they receive visits from Chinese businessmen promising significant investment projects.

\section{Conclusion}

In the last half century, Taiwan foreign aid activities have been important to promote the image of a nation willing to be involved in global affairs, promoting international development and offering humanitarian assistance. That contributes to the ROC's efforts to break international isolation and establish official diplomatic ties with an (admittedly small) number of developing countries. As we have seen in this article, Latin America and the Caribbean represent an important scenario in the rivalry between China and Taiwan for international diplomatic recognition, since slightly more than half of countries recognizing Taiwan are located in the region. In this competition, foreign aid is being used by both sides as a public diplomacy tool, and the amounts of loans, grants and technical assistance to the region have been substantial. Both China and Taiwan allocate to LAC countries a generous share of their foreign aid budget as compared to other donors (only Spain focuses on LAC in a greater proportion). Beijing is clearly favorite in this struggle, due to its superior economic power and its position of permanent member of the UN Security council. PRC has used its leverage to enforce the so-called "One-China policy", according to which other countries can only establish formal diplomatic ties with either the PRC or the ROC, but not with both at the same time. As a consequence, Taiwan has seen the number of countries that recognize it gradually diminish, reaching the lowest number of 17 countries during 2018.

From LAC point of view, Taiwanese aid to the region undoubtedly offer an important contribution to regional development, as well as helping with disaster recovery and resilience in Caribbean islands and 
Central American States. From Taiwanese perspective, its aid programs are important for its fundamental objective of maintaining some diplomatic recognition and, thus, avoid international isolation. Since Taipei cannot match Beijing "checkbook diplomacy" competition on a dollar for dollar base, Taiwan has been leveraging its comparative strengths: its reputation as an economic development miracle (potentially capable of substantial investment in the region in the ITC sector); its positive image as a country that promotes a form of development based on shared democratic values and human rights; its experience as a country able to resist a difficult natural environment that is subject to threats similar to those faced by LAC countries (such as hurricanes and earthquakes), and which is able to provide technical assistance to empower LAC communities (an approach that is very different from the top-down approach, focused on infrastructures, used by the PRC). Together with trade and investment relations, development aid plays a significant role to strengthen LAC ties to Taiwan.

Nevertheless, coming to the question of whether Taiwan's international status has been greatly improved by its aid programs, the answer that emerges from this article seems to be mixed. While Taipei has been relatively successful in the 1980s and 1990s, in the recent decade Taiwanese cooperation hasn't succeeded in its diplomatic objectives. In particular, during the last three years following President Tsai's election in Taiwan in 2016 (whose pro-independence statements have been considered unacceptable by Beijing), we assisted to significant renewed efforts by the PRC to impose a "one-China" policy in the region. That leverages potential increases in trade and investments, which in turn have been successful in prompting Panama, El Salvador and the Dominican Republic to cut their ties with Taipei and recognizing Beijing. Therefore, future research could focus on the importance of trade relations in LAC, rather than foreign assistance, for Taiwan recognition. In fact, all the evidence provided in this article indicates that, despite its considerable international aid efforts, Taipei cannot be too confident to succeed in retaining diplomatic recognition in the region. Facing the risk of further international isolation, the US and Taiwan are working together to find ways to encourage Latin American and Caribbean nations to maintain and improve their relations with Taiwan, thus extending the lifetime of the current status quo. 


\section{References}

Alexander, C. (2014). China and Taiwan in Central America. New York: Palgrave MacMillan, doi: https://doi.org/10.1057/9781137480101

Beech, E. (2018). U.S. recalls diplomats in El Salvador, Panama, Dominican Republic over Taiwan. Reuters. Available at: https://www.reuters.com/article/ us-usa-china-taiwan/u-s-recalls-diplomats-in-el-salvador-panama-dominicanrepublic-over-taiwan-idUSKCN1LO00N

Brautigam, D. (2010). China, Africa and the international aid architecture. African Development Bank Group Working Paper, 107.

Butterfield, S. (2004). US development aid--An historic first: Achievements and failures in the twentieth century (vol. 108). Greenwood Publishing Group.

Chan, G. (1997). Taiwan as an emerging foreign aid donor: developments, problems, and prospects. Pacific Affairs, 37-56, doi: https://doi.

org/10.2307/2761227

Chang, D. (1965). US Aid and Economic Progress in Taiwan. Asian Survey, 152-160, doi: https://doi.org/10.2307/2642405

Chen, J. (2002). Foreign policy of the new Taiwan: Pragmatic diplomacy in Southeast Asia. Edward Elgar Publishing.

Cheng, T. (1994). Foreign aid in ROC diplomacy. Contemporary China and the changing international community, 170-84.

Chiang, C., \& Hsu, E. (2018). U.S. calls for resumption of cross-strait talks. Focus Taiwan. July 25. Available at: http://focustaiwan.tw/search/201807250008. aspx?q=yeh

China's Policy Paper on Latin America and the Caribbean (2008). Available at: http://www.gov.cn/english/official/2008-11/05/content_1140347.htm

Ellis, R. E. (2009). China in Latin America: the whats and wherefores (vol. 46). Boulder, CO: Lynne Rienner Publishers.

Ellis, R. E. (2011). Chinese soft power in Latin America: A case study. National Defense Univ Washington DC.

Ellis, R. E. (2018a). Taiwan's Diplomatic Struggle in Latin America. The News Lens. Available at: https://international.thenewslens.com/article/109817

Ellis, R. E. (2018b). PRC Engagement in Latin America and Implications for Taiwan and the United States. Global Taiwan Brief, 3(12). Available at: http:// globaltaiwan.org/2018/06/13-gtb-3-12/

Erickson, D., \& Chen, J. (2007). China, Taiwan, and the battle for Latin America. Fletcher F. World Aff., 31, 69.

Esteban, M. (2007). The diplomatic battle between Beijing and Taipei in Latin america and the Caribbean. Chinese (Taiwan) Yearbook of International Law and Affairs, 25(1), 65-88.

Friedman, E. (2007). China's Changing Taiwan Policy. American Journal of Chinese Studies, 119-134. 
Gao, C. (2019). China-El Salvador Relationship Wobbles. The diplomat. March 18. Available at: https://thediplomat.com/2019/03/china-el-salvadorrelationship-wobbles/

Harold, S., Morris, L., \& Ma, L. (2019). Countering China's Efforts to Isolate Taiwan Diplomatically in Latin America and the Caribbean. Rand Corporation, doi: https://doi.org/10.7249/RR2885 Available at: https://www.rand.org/ content/dam/rand/pubs/research_reports/RR2800/RR2885/RAND_ RR2885.pdf

Her, K. (2012). Delivering Effective Aid, Taiwan Today, December 1, 2012. Available at: https://taiwantoday.tw/news.php? unit=4,29,29,31,45\&post=7953

Hernández, J. (2016). China suspends diplomatic contact with Taiwan. New York Times, June 25.

Herrera, J. (2019) The important role TaiwanICDF plays in Taiwan's diplomacy, Taipei Times, May 3. Available at: http://www.taipeitimes.com/News/feat/ archives/2019/05/07/2003714685

Herrera, J. (2019). The Nicaraguan loan controversy. Taipei Times. March 3. Available at: http://www.taipeitimes.com/News/editorials/ archives/2019/03/03/2003710735

Hickey, D. (1994). Coming In From The Cold-Taiwan Return To International Organizations. Issues E Studies, 30(10), 94-107.

Hsieh, C. C. (1985). Strategy for survival: The foreign policy and external relations of the Republic of China on Taiwan, 1949-79. Sherwood Press.

Hsieh, C. C. (1996). Pragmatic diplomacy: foreign policy and external relations. Take-off for Taiwan, 66-106.

Hsu, S. (2018). Nicaragua hails programs moved from El Salvador. Taipei

Times. Available at: http://www.taipeitimes.com/News/taiwan/ archives/2018/10/24/2003702937

ICDF (2017). 2017 Annual Report. Available at: http://www.icdf.org.tw/public/ MMO/icdf/2017\%20Annual\%20Report.pdf

ICDF (2019). International Cooperation and Development Fund. Available at: http://www.icdf.org.tw/

Kenney, M. (2004). Locating global advantage: industry dynamics in the international economy. Stanford University Press.

Koleski, K, \& Blivas, A. (2018). China's Engagement with Latin America and the Caribbean. USCC. Available at: https://www.uscc.gov/sites/default/files/ Research/China\%27s\%20Engagement\%20with\%20Latin\%20America\%20 and\%20the\%20Caribbean_.pdf

Lee, W. C. (1993). Taiwan's Foreign Aid Policy. Asian Affairs, 20(1), 43-62, doi: https://doi.org/10.1080/00927678.1993.10771147 Retrieved from http://www. jstor.org.ezproxy.uniandes.edu.co:8080/stable/30172174

Lee, W. C. (1994). ROC's foreign aid policy. In J. C. Hu (ed.), Quiet Revolutions on Taiwan. Republic of China, Taipei: Kwang Hwa Publishing Company, 331360. 
Lee, W. C. (2004). Field of Dreams: An Overview of the Practice and Study of Taiwan. Issues E Studies, 40(3-4), 137-182.

Li, H. (2005). Rivalry between Taiwan and the PRC in Latin America. Journal of Chinese Political Science, 10(2), 77-102, doi: https://doi.org/10.1007/ BF02877029

Lin, B. J. (1990). The Republic of China and Africa: a case of positive adaptation. Foreign Policy of the Republic of China on Taiwan: An Unorthodox Approach. New York: Praeger.

Lin, T. C. (1995). The ROC's Foreign-Aid And The Southward Policy. Issues $\mathcal{E}$ Studies, 31(10), 1-20.

Lin, T. C. (1996). Taiwan's foreign aid: an instrument of foreign policy. New Zealand Journal of East Asian Studies, 4, 58-80.

Lin, T., \& Lin, J. (2017). Taiwan's Foreign Aid in Transition: From ODA to Civil Society Approaches. Japanese Journal of Political Science, 18(4), 469-490, doi: https://doi.org/10.1017/S1468109917000135

Liu, P. (2009). Planting Rice on the Roof of the UN Building: Analysing Taiwan's "Chinese" Techniques in Africa, 1961-present. The China Quarterly, 198, 381400, doi: https://doi.org/10.1017/S0305741009000368

Lu, I., \& Hsiao, S. (2017). Taiwan force for good in world, US official says. Taipei Times. Available at: http://www.taipeitimes.com/News/taiwan/ archives/2018/04/28/2003692139

Lynch, D. (2011). Searching for Taiwan's Plan B'. The Diplomat, 23.

Maggiorelli (2017). Chinese Aid to Latin America and the Caribbean: Evolution and Prospects. Revista Internacional de Cooperación y Desarrollo, 4(2), 28-50. Available at: http://www.revistas.usb.edu.co/index.php/Cooperacion/ article/download/3335/2742

Malkin, E. (2017). Taiwan Works to Keep Its Central American Friends (Among Its Few). New York Times. January 13, 2017. Available at: https://www.nytimes. com/2017/01/13/world/americas/taiwan-president-tsai-central-americachina.html

Manthorpe, J. (2016). Forbidden nation: A history of Taiwan. St. Martin's Griffin. Menchu, S. (2017). Taiwan's Central American Allies Coy on Panama's Beijing Embrace. Reuters. June 13, 2017. Available at: https://www.reuters.com/ article/us-panama-china-centralamerica/taiwans-central-american-alliescoy-on-panamas-beijing-embrace-idUSKBN1942P9

Ministry of Foreign Affairs. (2016). Foreign Policy Guidelines. Available at https:// www. 外交部.tw/en/cp.aspx? n=B7411BDCD003C9EC

Ministry of Foreign Affairs. (2019). ROC Embassies and Missions Abroad. Available at https://www.roc-taiwan.org/

Möller, K. (1996). Does flexible diplomacy improve Taiwan's international status. The International Status of Taiwan in the New World Order: Legal and Political Considerations. Kluwer International Law, London The Hague Boston, 5362. 
Morgan, D. E. (2017). Trade Developments in Latin America and the Caribbean. Washington, DC: Monetary Fund: International Monetary Fund. Available at: https://www.imf.org/ /media/Files/Publications/CR/2017/cr1766-ap-5.ashx

Nicholson, G. (2015). Transport, Logistics and Competitiveness in the Caribbean. Caribbean Journal, September 2015. Available at: https://www.caribjournal. com/2015/09/04/transport-logistics-and-competitiveness-in-the-caribbean/

Ramos, A. (2017). Taiwan Gives Guatemala Over Us $\$ 600$ Million In Funding. Amandala. August 9. Available at: http://amandala.com.bz/news/taiwanguatemala-us600-million-funding/

Rich, T., \& Dahmer, A. (2017). Taiwan's Central America Dilemma. Taiwan Sentinel. September 21. Available at: https://sentinel.tw/taiwans-central-americadilemma/

Rich, T. (2009). Status for Sale: Taiwan and the Competition for Diplomatic Recognition, Issues Ẽ Studies, 45(4), 159-188.

Rich, T. (2010). Haitian Disaster Relief: Implications of Chinese and Taiwanese Assistance. The Newsletter, 53(Spring). Available at: https://www.iias.asia/sites/ default/files/nwl_article/2019-05/IIAS_NL53_09.pdf

Rubinstein, M. A. (1999). Political Taiwan ization and pragmatic diplomacy: The eras of Chiang Ching-kuo and Lee Teng-hui, 1971-1994. Taiwan: A new history, 436-80. Available at: http://faculty.washington.edu/stevehar/Rubenstein $\% 20$ democratization.pdf

Statement from the Press Secretary on El Salvador (2018). White House. Available at: https://www.whitehouse.gov/briefings-statements/statement-presssecretary-el-salvador/

Sullivan, M., \& Lum, T. (2019). In Focus: China's Engagement with Latin America and the Caribbean. Washington D.C.: Congressional Research Service, 7-5700, April 11. Available at: https://fas.org/sgp/crs/row/IF10982.pdf

Taylor, I. (1998). China's foreign policy towards Africa in the 1990s. The Journal of Modern African Studies, 36(3), 443-460, doi: https://doi.org/10.1017/ S0022278X98002857

The Taiwan Loan Controversy: Loan Of US $\$ 100$ Million Gives Lifeline To Ortega (2019). Q costarica. March 6. Available at: https:/qcostarica.com/the-taiwanloan-controversy-loan-of-us100-million-gives-lifeline-to-ortega/

Transparency International (2019). Corruption Perception Index (CPI). Available at https://www.transparency.org/cpi2018

Tubilewicz, C. (2007). Taiwan and post-communist Europe: Shopping for allies. Routledge, doi: https://doi.org/10.4324/9780203946978

Tubilewicz, C. (2016). State transformation and the domestic politics of foreign aid in Taiwan. The Pacific Review, 29(1), 45-66, doi: https://doi.org/10.1080/09512 748.2015.1066412

Tubilewicz, C., \& Guilloux, A. (2011). Does size matter? Foreign aid in Taiwan's diplomatic strategy, 2000-8. Australian Journal of International Affairs, 65(3), 322-339, doi: https://doi.org/10.1080/10357718.2011.563777 
Wang, C. (1995). The Republic of China's Foreign Policy 1949-1988: Factors Affecting Change in Foreign Policy Behaviour. Ann Arbor: University Microfilms International.

Wang, T. Y. (2002). Taiwan's foreign relations under Lee Teng-Hui's rule, 19882000. American Asian Review, $20(1), 71$.

Wu, L. J. (1995). Does money talk? The ROC's economic diplomacy. Issues $\mathcal{E}$ studies, 31(12), 22-35.

Yeh, J. (2019). No El Salvador decision made on possibly resuming ties with Taiwan. Focus Taiwan. March 14. Available at: http://focustaiwan.tw/news/ aipl/201903140007.aspx 